\title{
EFFECT OF MILRINONE ON BIVENTRICULAR DIASTOLIC FUNCTION
}

André Y. Denault MD FRCPC, Pierre Couture MD FRCPC, Michel Pellerin MD FRCSC Jean-Claude Tardif MD FRCPC

Departments of Anesthesiology, Cardiac Surgery, and Cardiology, Montreal Heart Institute, 5000 Bélanger Street, Montreal, Quebec H1T 1C8

INTRODUCTION: Patients with left ventricular diastolic dysfunction (LVDD) are at higher risk of hemodynamic instability after coronary artery bypass $(\mathrm{CABG})^{1,2}$. We hypothesized that prophylactic administration of milrinone improves biventricular diastolic function in patients with known LVDD undergoing CABG.

METHODS: After Ethic and Research Committee approval, 50 patients undergoing CABG were randomized to receive milrinone $(\mathrm{M})$ or placebo (P). In the $\mathrm{M}$ group, a bolus dose of $50 \mu \mathrm{g} / \mathrm{kg}$ over $10 \mathrm{~min}$ was given, followed by an infusion rate of $0.5 \mu \mathrm{g} / \mathrm{kg} / \mathrm{min}$ until skin closure. Hemodynamic and transesophageal echocardiographic (TEE) measurements of systolic and diastolic functions were done before and after the bolus, and after CPB. To evaluate diastolic function, we measured the pulsed wave (PW) Doppler of the transmitral and transtricuspid inflow (TMF and TTF, E and A wave), pulmonary and hepatic venous flow (PVF and HVF: S, D and Ar waves at atrial contraction). Mitral (Em, Am) and tricuspid annulus velocities (Et, At) were assessed by tissue Doppler imaging (TDI). LVDD was classified as: grade 1 (TMF E/A $>1$, PVF $\mathrm{S} / \mathrm{D}>1, \mathrm{Em} / \mathrm{Am}>1)$, grade $2(\mathrm{E} / \mathrm{A}>1, \mathrm{~S} / \mathrm{D}>1, \mathrm{Em} / \mathrm{Am}<1)$, grade $3(\mathrm{E} / \mathrm{A}<1, \mathrm{~S} / \mathrm{D}>1, \mathrm{Em} / \mathrm{Am}<1)$, grade $4(\mathrm{E} / \mathrm{A}>1, \mathrm{~S} / \mathrm{D}<1, \mathrm{Em} / \mathrm{Am}<1)$, grade $5(\mathrm{E} / \mathrm{A}>2, \mathrm{~S} / \mathrm{D}<1, \mathrm{Em} / \mathrm{Am}<1)$. RVDD was classified as: grade 1 (TTF $\mathrm{E} / \mathrm{A}>1, \mathrm{HVF} \mathrm{S} / \mathrm{D}>1, \mathrm{Et} / \mathrm{At}>1$, grade $2(\mathrm{E} / \mathrm{A}<1$, or reversed $\mathrm{Ar}>50 \%$ of $\mathrm{S}$, or Et/At $<1$ when both $\mathrm{E} / \mathrm{A}$ and $\mathrm{S} / \mathrm{D}>1)$, grade $3(\mathrm{E} / \mathrm{A}>1, \mathrm{~S} / \mathrm{D}<1)$, grade 4 (S wave reversal on $\mathrm{HVF}$ ). ANOVA and Wilcoxon tests were used for analysis. $\mathrm{P}<0.05=$ significant.

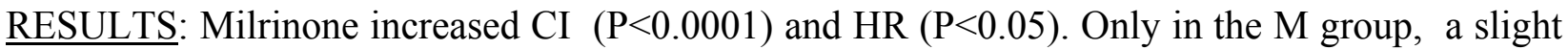
worsening in LVDD scores after the bolus was observed, which returned to baseline after CPB. No change in RVDD scores was observed. Higher PVF $\mathrm{S}$ wave $(\mathrm{P}=0.0021)$, HVF $\mathrm{S}$ wave $(\mathrm{P}=0.026)$, TTV A wave $(\mathrm{P}=0.0358)$ and At measured by DTI $(\mathrm{P}=0.0109)$ were observed in the $\mathrm{M}$ group. $\mathrm{M}$ group required more phenylephrine $(\mathrm{P}<0.05)$.

DISCUSSION: Prophylactic milrinone is associated with improved systolic function but is not associated with improved biventricular diastolic function in patients undergoing CABG.

REFERENCES: 1- Anesth Analg. 92:291-298. 2- Am J Cardiol. 91:550-554.

Supported by Dr Earl Wynands Research Award in Cardiovascular Anesthesia. 